\title{
AN ANALYSIS OF PROFESSOR LOURENS DU PLESSIS' EARLY (PRO-LIFE) AND LATER (PRO- CHOICE) PERSPECTIVES ON ABORTION
}

\author{
Najma Moosa \\ BA LLB LLM LLD \\ Professor, Department of Private Law \\ University of the Western Cape
}

SUMMARY

Abortion, or termination of pregnancy, albeit in gradations from most to less restrictive to unrestricted, has always been legally allowed in South Africa. This questions the need for the introduction of new law. Legalisation of abortion has reduced abortion to a form of failed contraception. Illegal abortions motivated new law, as well as research, Professor Lourens Marthinus du Plessis', ${ }^{11}$ constitutional argument favouring women's (reproductive) right to abortion. Yet, illegal abortions continue as before democracy when the seemingly Christian, racially-motivated law, was flouted by white and black women alike. The Constitution adopts a neutral position on the right to life, but is decidedly pro-abortion. This does not imply that a constitutional challenge, which has yet to occur, seeking to amend the current status quo and to provide protection to an unborn, may be an exercise in futility. This article is written in honour of, and analyses the role and early "pro-life" views of the now retired Du Plessis as a white Afrikaner male, husband, father and proud grandfather schooled in a traditional, conservative strand of Christianity, and as an anti-apartheid constitutional lawyer and drafter - to determine whether his liberal political views are compatible with his moral views and whether they may have since changed.

\section{$1 \quad$ INTRODUCTION}

Why abortion, why Prof Lourens du Plessis and why me?

\footnotetext{
Lourens Marthinus du Plessis (Hons BA (Stellenbosch), B Jur et Comm, LLB, B Phil, LLD (PU vir $\mathrm{CHO})$ ) has recently formally retired from academia, although he remains an Extraordinary Professor of Law at North-West University (Potchefstroom). This article is written as a small token in honour of his profound role as my mentor and teacher. Prof Du Plessis has always insisted that I address him by his first name - a request I have hitherto denied him out of deference to his status. Personal information was obtained informally through e-mails and telephonic conversations with him and is used with his permission. Afrikaans texts were translated into English to facilitate their understanding. I thank Professors $\mathrm{J}$ de Ville for his assistance with the translations, and I Leeman for his editorial assistance.
} 
Abortion, or termination of pregnancy, has always been legally "allowed" in South Africa, albeit in gradations from most restrictive in terms of the common-law, to less restrictive during the operation of the first statute to regulate it during apartheid from 1975, namely, the Abortion and Sterilisation Act $(A S A)^{2}$, to unrestricted since 1996, when the ASA was replaced by the current statute regulating it, namely, the Choice on Termination of Pregnancy Act (CTOPA). ${ }^{3}$

What, therefore, motivated me to revisit a topic that may not hold much current relevance for many, and, moreover, to do so in the context of a protagonist whose early views and publications on abortion may be dated, because they were either based on the ASA or interim Constitution (1993) ${ }^{4}$ and current Constitution (1996) $)^{5}$ (the Constitution), and did not include the CTOPA? I do so for several reasons.

I contend that Prof Du Plessis' last article (1996), which contains his most recent interpretations pertaining to abortion, although it was written in a purely constitutional context, displayed remarkable political acuity of, consciousness of, and grappling with, the fact that "moralities" have to be tempered with the "realities" that the ravages of apartheid had left behind as a legacy for the majority of South Africa's impoverished people, when it came to the question of "unwanted" (accidental) children or "back-street" (illegal) abortions, and which still continue. ${ }^{6}$ This article, although it provides a comprehensive analysis of, and comparison between, Prof Du Plessis' early and later positions on abortion, excludes a review of the CTOPA because his position had stopped short of it. However, the CTOPA, unlike the ASA, has adopted, and operates within, a convenient trimester approach. Although it affords women alone a clear right to request an abortion during the first two trimesters, the fact that it makes provision for abortion within restricted timeframes may mean that it has not sounded a future death-knell for the right of an unborn to life. Hence, reference is briefly made to the CTOPA where it may shed light on Prof Du Plessis' views in a current context.

Section Three highlights that the ASA legally permitted abortion and was deemed liberal by the standards of the apartheid Government that had introduced it. A valid question that this article therefore addresses is whether it may have been necessary in the first place to have replaced the ASA with the CTOPA, or, whether it would have sufficed to have merely amended it. Section Three also highlights that both the interim and current Constitutions adopt a neutral position on the right to life, and therefore do not guarantee women the right to an abortion. Despite the leeway implicit in such a position

\footnotetext{
2 of 1975.

92 of 1996. Enacted on 11 December 1996 and entered into force on 1 February 1997.

Constitution of the Republic of South Africa, Act 200 of 1993. Effective from 27 April 1994 until 3 February 1997

Constitution of the Republic of South Africa,1996. Effective from 4 February 1997.

6 See Farber "Illegal Abortion Drug Horror" 1 April 2014 Cape Times 1 and 3; and Blackie "Fact Sheet on Child Abandonment Research in South Africa" 20 May 2014 National Adoption Coalition South Africa http://www.adoptioncoalitionsa.org/wp-content/uploads/ 2014/05/Fact-Sheet-Research-on-Child-Abandonment-in-South-Africa_Final2.pdf (accessed 2015-01-05).
} 
in the interim Constitution (a position which he had helped to shape), Prof Du Plessis interprets the current Constitution as going further by containing yet other provisions which clearly favour reproductive health that add to, rather than detract from, the right to an abortion. However, the Constitution does not guarantee women the right of access to an abortion because it treats access as a socio-economic right. Given that the Constitution also guarantees the right to freedom of religion and the practice thereof, the potential for conflict between this right and other constitutional rights inter se remains unavoidable. Section Three broadly examines Du Plessis' academic position on abortion through the lens of his personal life and in a political context to better understand his views. It was constructed with the following questions in mind: Was he merely a neutral observer imagining that the public-law views that he had expressed in the 1970s during apartheid, and as an anti-apartheid constitutional lawyer during the drafting of the 1993 Constitution, were not influenced by his personal experience as a husband, and father, and the convictions that he professed to hold? What, if any, was the impact of his upbringing in a religiously (Christian), culturally (Afrikaner) and politically (white) conservative society on the views he held? Section Three also highlights that the Constitutional Court, which has hitherto only addressed the right to life in the context of capital punishment, has yet to do so in the context of abortion.

This article will highlight that Prof Du Plessis not only carried his personal (Christian and moral) opinions on abortion close to his heart, but also wore his heart on his sleeve when he had the courage of his convictions to express, and justify, a pro-life proclivity. However, in doing so, Du Plessis' earlier held pro-life views had earned him harsh criticism from one of his postgraduate students, Sarkin ${ }^{7}$, who had espoused a secular, pro-choice view on abortion in a doctorate that was penned under his supervision. In his doctorate Sarkin wrote the following in the context of Du Plessis' first (1990) sole-authored article on abortion:

"[While] Du Plessis may aver that 'pre-natal and post-natal life are both life and ought to be respected and protected accordingly,' ... this deserves consideration [only] as an opinion ... and may well be not only a minority opinion but an ill-considered one."

For this reason Section Four examines Prof Du Plessis' academic position with the following questions in mind: Did his research and expertise as an "interpreter" of statutes reflect absolutist anti-abortion views, and any disingenuous "editing" of texts in favour of life, or did they embody nuanced views of tolerance for ambiguity and complexity on the matter of abortion? Based on the answers to these questions, I contend that even if Sarkin's criticism were justified, because it was seen in isolation of these contexts and other more liberal views expressed by Du Plessis, it may not have been entirely objective and may also have been biased by the subjectivities of his own personal context. I have, owing to space constraints, only used one of

\footnotetext{
Sarkin The Effect of a Constitution and Bill of Rights on Abortion in South Africa: A Comparative Study (LLD Thesis, University of the Western Cape 1992-1995).

8 Sarkin (LLD Thesis, University of the Western Cape 1992-1995) 316.
} 
several such references by Sarkin in support of my contention and acknowledge the shortcomings of generalising implicit therein.

Like Sarkin I too have a similar connection to him. I was the first black (using the inclusive term) doctoral student that Du Plessis had supervised and he was my first post-apartheid mentor.

In broadly ascertaining whether or not Sarkin's criticism was warranted, given that Du Plessis, it appears, had in fact deemed the ASA to be more liberal than necessary, I decided to analyse some of Du Plessis' early views in more detail in Sections Four and Five, and do so specifically in the context of Christianity in South Africa in Section Five. Section Four interrogates the degree to which Du Plessis was pro-life, and considers some of his novel, if not radical and controversial, propositions and ideas on life that many readers may not be aware of in order to highlight that his being pro-life did not necessarily mean he was anti-choice in all cases.

Abortion is not a simple "black and white" issue in South Africa and remains a contentious religious and legal topic that raises more questions than for which there are ready answers. South Africa had, with democracy, become a secular state without an official state religion. Nonetheless, Section Five highlights that Christianity was the dominant religion during apartheid and probably still is. While Du Plessis' early pro-life and personal views on abortion, therefore, may have been influenced by his strong affiliation to Christianity, it did not appear to have had an impact on his ability to objectively and critically analyse and interpret the "liberal" provisions of the ASA, although he may have been personally conflicted in doing so. Section Five questions whether Christianity, in the past or currently, can be deemed to have really defended or influenced the interpretation of the right to life in favour of an unborn in South African law, given that it clearly links the start of life to both birth and age.

Sections Four and Five also serve to set the context within which to gauge whether there were a preserving of, or shifting in, his earlier perspectives on abortion, and whether they still resonate as strongly with him now, in the twilight years of his life, as they did then in its heyday. Given that I had made certain assumptions, and drawn certain conclusions, based on what $\mathrm{Du}$ Plessis had written, but that I was also uncertain about some of these views, I have, instead of speculating, directly engaged Du Plessis on it, the outcome of which is detailed in Section Six.

Section Seven concludes the article. Of the several important points that it raises, two are highlighted. First, while it may appear that, from the point of view of both legalisation and the Constitution itself, there seems to be little point for pro-lifers to legally or even constitutionally challenge the right to abortion, given that it will more than likely be unsuccessful, since there has as yet not been a Constitutional Court challenge which pertains directly to abortion and which provides a last word on it, the abortion issue as yet may not have been decided "once and for all" as many believe it has. Secondly, it remains necessary to interpret the provisions of the Constitution (albeit implicit) in support of the right to abortion because of a fact that Du Plessis had more than a decade ago already alerted us to, namely, that the "prosperity gap" between the $20 \%$ rich (overwhelmingly white) and the $80 \%$ 
poor population in South Africa has not been closing fast enough since the advent of democracy. ${ }^{9}$

\section{PROF DU PLESSIS IN SUPPORT OF A WOMAN'S CONSTITUTIONAL RIGHT TO ABORTION}

South Africans had held opposing views on abortion during the operation of the ASA. This was highlighted and clarified by Du Plessis in 1990 and 1991 as follows:

"[T]here are those who advocate a so-called liberalization of abortion legislation ... so that medically safe abortions will be available more freelyand perhaps even on demand ... Public opinion ... seems to favour lawful abortion on the grounds presently provided for by the [ASA] and is against abortion for socio-economic reasons. ${ }^{10} \ldots[\mathrm{H}]$ owever, the results of certain opinion surveys seem to indicate support for the "liberalization" of abortion legislation."

Large numbers ${ }^{12}$ of illegal abortions may have been touted as a main motivating factor for introducing the CTOPA. In 1996 Du Plessis had proffered a Christian assessment of abortion in the context of the Constitution which indicated support for the need to introduce the right to abortion:

"To many Christians in South Africa fetal life is of such fundamental religious significance that they cannot accept that an abortion can be procured in circumstances other than an emergency. I, for one, respect this view because I also revere fetal life. However, people holding this view will have to advance credible (and workable) solutions to the following two real problems:

1. Who is to care for and raise "unwanted" children born into a situation of poverty and misery?

2. How are we to deal with the evil of 'backstreet abortions' which kill or do serious bodily and mental harm to many thousands of women each year?

Problems such as these lay a foundation for cogent constitutional arguments in favour of women's right to a (safe) abortion."

As pro-life as Du Plessis indicated that he then still was, he appears to give an indication that he may have had a change of heart, and that his view may no longer be as firmly rooted in Christianity as it had been prior to that. I base my assumption on the fact that Du Plessis had in 1990 clearly articulated support for a pro-life view when he not only referred to an unborn as a "human being", but also advanced the argument that every unborn be given the right to a start to life that would include forming part of a family, whether wanted or unwanted. Was this a "Freudian slip" or a matter of

9 Du Plessis "The Future of South Africa: Perspectives of Integrating Different Cultures Means of Law" 20026 Rechtspolitisches Forum 5.

10 Du Plessis "Jurisprudential Reflections on the Status of Unborn Life" 19901 TSAR 48.

11 Du Plessis "Reflecting on Law, Morality and Communal Mores (With Particular Reference to the Protection of Pre-natal Life)" 1991 56(3) Koers 347.

12 Sarkin (LLD Thesis, University of the Western Cape 1992-1995) 63.

13 Du Plessis "A Christian Assessment of Aspects of the Bill of Rights in South Africa's Final Constitution" 199696 Journal of Theology for Southern Africa 72-73. 
terminological semantics on the part of Du Plessis, given that it was (and still is) technically incorrect to refer to an unborn as "human"?

\begin{abstract}
"Has the foetus not got an own standing in (for example) the family into which it is to be born? ... Birth is the fulfilment of one of the most vital expectations of the foetus ... Birth is not the beginning of life; it is simply a drastic switch in lifestyle ... I am, to say the least, uneasy about some of the [ASA] grounds [which go beyond necessity] on which a lawful abortion can be procured ... 'Once the sanctity of human life is degraded, society stands at the top of a slippery slope that could lead to abortion on demand (of the mother) [and] ... abortion on command (of the State) ...'”14.
\end{abstract}

What I did initially find surprising is why Du Plessis had not included the CTOPA within the ambit of his article, given that the Constitution came into operation just three days before the CTOPA which must therefore, at least, have been available in Bill form. Furthermore, in the previous year (1995), Du Plessis had completed the supervision of Sarkin's doctorate on abortion, although it was based on the interim Constitution and finalised before both the current Constitution and the CTOPA.

Although Du Plessis may have overlooked the latest developments with regard to the CTOPA because his attention was occupied with more pressing matters, he nevertheless kept himself connected to the topic. Du Plessis had supervised both Sarkin and me at more or less the same time between 1993 and 1996 when South Africa was busy transitioning from apartheid to democracy, and he was destined to play an instrumental role in shaping the neutral position on the right to life provision (and therefore abortion) in South Africa's first justiciable Bill of Rights contained in the interim Constitution. Section Three investigates Du Plessis' role in this process and the conflict within the Constitution itself.

\title{
3 DU PLESSIS AND THE ASA IN HISTORICAL, PERSONAL, POLITICAL, CONSTITUTIONAL AND JUDICIAL CONTEXTS
}

With the advent of democracy in South Africa in 1994 came the end of 46 years (since 1948) of apartheid rule by the minority, all white, Afrikanerdominated National Party (NP) Government. Given a context of Dutch and British colonial rule, the NP's following included most of the Dutch descended Afrikaners and many English-speaking whites. The African National Congress (ANC) has been the ruling power ever since.

Du Plessis reminds us that "[a]partheid ... was the social experiment of a 'Christian government' which, in its laws, clearly favoured Christianity ..."15 Further, that it was through the collaborative effort of three Reformed Afrikaans churches, which included the Dutch Reformed Church, which both shaped and formulated the theological justification given to apartheid. ${ }^{16}$

\footnotetext{
Du Plessis 19901 TSAR 58

Du Plessis 199696 Journal of Theology for Southern Africa 74.

16 Du Plessis and Gouws "The Relationship Between Political Tolerance and Religion: The Case of South Africa" 2000 14(2) Emory International LR 660.
} 
Although this may partly explain the restrictive nature of abortion law during the operation of both the common law and the ASA, I contend in Section Five that Christianity may in fact have had very little to do with it.

Prior to, and until, the enactment of the ASA, abortion in South Africa had not been statutorily defined. Hence guidance as to what exactly it was that abortion law entailed had to be sought from South Africa's Roman-Dutch common law and case law. The common law had severely restricted abortion and considered it to be a crime, albeit with one exception (defence of necessity) - a therapeutic abortion was legally allowed only if medically the life of the mother was in danger and had to be saved. ${ }^{17}$

The ASA was intended to clarify the application of the common law. ${ }^{18}$ Although the expectation was high that the ASA be a progressive law, ${ }^{19}$ Hawthorne ${ }^{20}$ pointed out that its aim was deemed to be to protect the "potential" life of the foetus against its killing.

Professor Du Plessis married his wife, Wilhelmina, in 1971 and fathered three daughters born in 1974, 1975 and 1979. In 1973, the NP Government appointed an "all white", male only Commission of Inquiry ${ }^{21}$ to review the problem of abortion in South Africa. In 1974 it favourably considered its recommendations, and in 1975 it enacted the ASA.

Abortion remained illegal ${ }^{22}$ and the ASA provided for several categories of offences. However, it retained the common-law therapeutic exception ${ }^{23}$, and extended the circumstances for allowing an abortion to include eugenic ${ }^{24}$ and humanitarian ${ }^{25}$ considerations. ${ }^{26}$ It did so with no time restrictions and therefore made no distinction as to the "age" of an unborn. Viability (ability of a foetus to independently survive outside the uterus or womb of its mother) therefore appears not to have played as crucial a role in abortion legislation in South Africa prior to its legalisation as it currently does. However, as will be detailed in Sections Five, although "foetus" has not been defined in the ASA, and is not classified as a person in terms of South African law until its birth, this does not mean that a foetus was (as is still the case) necessarily without protection.

Hawthorne ${ }^{27}$ pointed out that the mere existence of the ASA provided a sufficient basis for the protection of the rights of prospective fathers. Was it therefore surprising that Du Plessis, who had fathered two daughters during

17 Hawthorne The Crime of Abortion: A Historical and Comparative Study (Unpublished LLD Thesis, University of Pretoria 1982) 223-224 and 237.

18 Hawthorne (Unpublished LLD Thesis, University of Pretoria 1982) 238.

Strauss "Therapeutic Abortion and South African Law" 196885 SALJ 459.

Hawthorne (Unpublished LLD Thesis, University of Pretoria 1982) 252.

21 Sarkin-Hughes and Sarkin-Hughes "Choice and Informed Request: The Answer to Abortion: A Proposal for South African Abortion Reform" 19901 Stell LR 373.

$22 \mathrm{~S} 2$.

$\mathrm{S} 3(1)(\mathrm{a})$ and $(\mathrm{b})$.

S 3(1)(c). An abortion is permitted if the pregnancy would end in the birth of an infant with a severe mental or physical abnormality.

$25 \mathrm{~S} 3(1)(d)$. An abortion is permitted if the pregnancy resulted from rape or incest.

26 S 3(1)(a)-(e).

27 Hawthorne (Unpublished LLD Thesis, University of Pretoria 1982) 278. 
the period that the ASA was being considered and reviewed, viewed the matter of liberalisation differently (conservatively) when he wrote of the ASA that

"[a] true liberalization of abortion legislation will be directed at the increased protection of the foetus's basic right to live-not at its increased subversion".

In 1977, shortly after the enactment of the ASA, Du Plessis was part of the Christian voice "that questioned the basic tenets of apartheid". ${ }^{29}$ Furthermore, in 1987 and 1989, Du Plessis was intimately involved with having discussions with members of the then banned ANC. During the transitional period leading up to and following the first democratic elections in April 1994, South Africa was governed by the interim Constitution. It was therefore not surprising that Du Plessis played a fundamental role in this process. Du Plessis opined that the interim Constitution had brought with it the end of "an era of privileging certain understandings of the Christian faith". ${ }^{30}$ In 1993, he was appointed Convenor of the Technical Committee on Fundamental Rights which was responsible for drafting South Africa's first Bill of Rights during the transition to democracy at the Multi-Party Negotiating Process in Kempton Park. ${ }^{31}$ Although Du Plessis ${ }^{32}$ points out that generous provision was made for the protection of an "impressive catalogue" of human rights in the Bill of Rights, the interim Constitution, which was "[t]he product of intense negotiation", did not deal with the question of abortion because of disagreement between the negotiators. In seeking to reach a compromise between the two opposing views on abortion, the Constitution makers adopted a neutral position on the right to life in both Constitutions:

Section 9 of the interim Constitution simply stated that "[e]very person shall have the right to life", while section 11 of the current Constitution states that "[e]veryone has the right to life".

Neither Constitution therefore expressly provides for the right to an abortion on request.

Du Plessis had pointed out that the interim Constitution also paved the way for the current Constitution. ${ }^{33}$ The neutral position had continued unchanged in the Constitution because, as indicated by Du Plessis, "[t]he constitution-makers avoided dealing with abortion as a predominantly right to life (or an exception to the right to life) issue". ${ }^{34}$ Given its controversial nature

Du Plessis 19901 TSAR 59

29 Eloff "Keynote Address: A Tribute to a Man who Served his Country and Humanity (Message on the occasion of the presentation of an honorary doctorate to Archbishop Desmond Tutu on 27 November 2002)" 2003 68(1) Koers 8.

30 Du Plessis "Freedom of or Freedom from Religion? An Overview of Issues Pertinent to the Constitutional Protection of Religious Rights and Freedom in 'the New South Africa"' 20012 Brigham Young University LR 442.

31 Du Plessis and Corder Understanding South Africa's Transitional Bill of Rights (1994) v.

32 Du Plessis 20012 Brigham Young University LR 440-441.

Du Plessis 20012 Brigham Young University LR 440.

Du Plessis 199696 Journal of Theology for Southern Africa 72. 
it was deemed to be the "Solomonic solution", ${ }^{35}$ that is, a middle course between the retention and the abolition thereof. However, Albie Sachs, ${ }^{36}$ of the ANC constitutional committee, may have given better expression to what this really meant when he stated that those against abortion will not have a right to impose positions on others with different (presumably pro-choice) opinions.

Du Plessis writes that whilst the abortion debate was more focused on the "desirability" of the law as it then stood up until the interim Constitution and its Bill of Rights, with the latter's commencement it was inevitable that the focus would shift to its "constitutionality". ${ }^{37}$

The "tug-of-war" that had ensued between "minimalists" (mainly the ANC) negotiators and "optimalists" over the matter had eventually resulted in a compromise with the ANC negotiators who made it quite clear from the outset that abortion was for them one of those issues that could only be settled in a final Bill of Rights that was drafted by a truly representative body. ${ }^{38}$ However, this is to be questioned, because what eventually did transpire was "that the matter [was] ... decided not so much by the (constitutional) court but through 'legislative action after democratic discussion in future'" ${ }^{39}$ This also goes a long way towards explaining why the CTOPA (which legalised abortion) preceded the Constitution (neutral position on abortion), and why it was not even necessary for the ASA, which essentially proscribes abortion, to be given the death-knell by a constitutional or judicial challenge.

Both Constitutions had adopted a neutral position on abortion when they made equal provision for the rights of a woman to privacy, ${ }^{40}$ reproductive freedom and physical integrity and the State's duty to protect the developing life ${ }^{41}$ that she carries.

Du Plessis wrote that "[t]he constitutionality of capital punishment or of legislation permitting abortion largely depends on the limitability ... of the right to life". ${ }^{42}$ The limitation clause (section 33(1)(b)) of the interim Constitution) provided for a limitation of each right contained in the Bill of Rights, including the right to life, only if such limitation did "not negate its essential content". The then Chief Justice, Corbett, in a memorandum submitted on behalf of the judiciary of South Africa on the Draft Interim Bill of Rights, had therefore appeared to suggest that both the death penalty and abortion were to be prohibited. Du Plessis highlighted that this may well be true, based purely on a literal interpretation of the clause. However, his prolife view, which would have favoured such an exacting position, did not cloud his expert judgment as an interpreter of statutes as is evident from his

\footnotetext{
See S v Makwanyane 1995 (3) SA 391 (CC) par 22.

Sachs Protecting Human Rights in a New South Africa (1990) 68.

Du Plessis "Whither Capital Punishment and Abortion under South Africa's Transitional Constitution?" 1994 7(2) SACJ 145.

38 Du Plessis 1994 7(2) SACJ 146-147.

39 Du Plessis 1994 7(2) SACJ 162.

40 S 13 and 14 of the 1993 and 1996 Constitutions, respectively.

41 S 9 and 11 of the 1993 and 1996 Constitutions, respectively.

42 Du Plessis 1994 7(2) SACJ 148.
} 
comment ${ }^{43}$ on the Chief Justice's view which did not deem the limitation clause to rule out the possibility of abortion.

Du Plessis had predicted that, if the Constitutional Court were to take its cue from private law, it would probably not recognise the foetus as a legal subject worthy of constitutional protection. ${ }^{44}$ However, during the period of the operation of the interim Constitution, the Constitutional Court in $S v$ Makwanyane, ${ }^{45}$ the first case since its inception, abolished the death penalty. It had therefore considered the right to life in the context of capital punishment and not abortion.

Several other provisions in the current Constitution clearly conflict with this neutral position because it also grants a pregnant woman the right to reproductive autonomy, and therefore comes very close to providing a woman with a right to abortion which overrides the rights of the unborn that she is carrying. For example, section 12(2)(a) explicitly recognises the right to make decisions concerning reproduction as part of the right to bodily and psychological integrity. By specifically guaranteeing the reproductive rights and health of women, this section goes further than the interim Constitution. Hence, Du Plessis ${ }^{46}$ opined, with regard to section 12(2), that:

"strengthened by the recognition, in [its] paragraph (b), of everyone's 'right ... to security in and control over their body ... [that] [t]he conclusion that the final Constitution does provide for women's effectual right to have an abortion thus seems to be unavoidable ... Section 12(2) must thus be understood as permitting optimal access by choice to the means for terminating a pregnancy in the most humane way. The section 7(2) duty of the state to promote and fulfill, amongst others, women's rights, read with the entrenchment of the right to health care services in section 27(1)(a), moreover strongly indicate that abortion services will have to be made available to indigent women by the state."

The human rights contained in the Bill of Rights are not absolute. Section 7 (3) provides that "[t]he rights in the Bill of Rights are subject to the limitations contained or referred to in Section 36, or elsewhere in the Bill". Thus, the section $27(1)(a)$ right to access health-care services is dependent on the availability of State resources (section 27(2)), and may therefore be limited, in terms of section 36 (general limitation clause), where these are deficient or lacking. Is it then not logical to conclude, that from the State's perspective, the right to an abortion literally boils down to a "request" and not a "demand"?

In terms of the interpretation clause (section 39 (1)(a) of the Constitution) of the Constitution, South Africa is only obliged to apply the provisions of international United Nations (UN) instruments once it has ratified them.

Although the right to an abortion may be inferred from it, the Constitution does not contain a clear right to abortion, nor does it guarantee access to an

See Du Plessis 1994 7(2) SACJ 152-153.

44 Du Plessis 1994 7(2) SACJ 162.

45 S v Makwanyane supra par 22. Mahomed J, (par 268) and O'Regan J, (par 326), in their respectively separate judgments concurring with Chaskalson $P$, in this matter, ruminated on some of the (interim) constitutional implications of abortion.

46 Du Plessis 19901 TSAR 72-73. 
abortion. Although the interpretation clause (section 39(1)(a) and (b)) of the Constitution uses imperative language when it states that a court "must consider international law" when interpreting the Bill of Rights, this consideration does not mean that it is obliged to "apply" the provisions of international human-rights instruments, unless South Africa has also ratified them. South Africa has ratified a range of United Nations (UN) instruments, for example, the Convention on the Rights of the Child (CRC) was ratified in $1995 .{ }^{47}$ Yet, the CRC does not guarantee children that basic, yet necessary, right to a "start" to life itself that Du Plessis deemed crucial. While it signed both the International Covenant on Civil and Political Rights (ICCPR) and the ICESCR in 1994, and had already ratified the ICCPR in 1998, the South African Government has ratified the ICESCR only as recently as January 2015. It is contended that the reason for the delay in ratifying the ICESCR may have been related to the creation of further financial expectations from, and strain on, State resources. Furthermore, little reliance or further guidance can be obtained from the provisions of the ICCPR: for example, see Article 6(1) for an interpretation contrary to that of section 11 (right to life) of the Constitution.

A further conflict is evident in yet another important constitutional provision, namely, section 15(1) which provides that "everyone has the right to freedom of conscience, religion, thought, belief and opinion". This provision appears to be wide enough to be invoked by all interested parties who may raise valid objections to abortion, including objectors who may voice moral objections or theorise about them, but who can safely, and even hypocritically, ignore these views in their private lives.

Yet, the Constitution is expected to provide interpretative guidance with regard to ambiguous or conflicting provisions within the CTOPA, and to do so in spite its own conflicting provisions in this regard.

While it was understandable that the ANC would want to review all apartheid legislation, one may in hindsight, question why the ANC deemed it necessary to choose to repeal the ASA which allowed abortion, given that in doing so it did not mean that it would prevent a judicial challenge, and whether this may have had anything to do with the fact that "[o]verall there were more "pro-life" than "pro-choice" submissions" that were made to the Ad Hoc Committee on Abortion and Sterilisation ${ }^{48}$ which reviewed the ASA, which therefore had to have been discounted.

47 See "Ratification of International Human Rights Treaties - South Africa" University of Minnesota, Human Rights Library http://www1.umn.edu/humanrts/research/ratificationsouthafrica.html (accessed 2015-01-05).

48 Moosa "A Descriptive Analysis of South African and Islamic Abortion Legislation and Local Community Responses" 2002 21(2) Medicine and Law 265. Nkomo Republic of South Africa. Report of the Ad Hoc Select Committee on Abortion and Sterilization [C3-95] vi. 


\title{
4 HOW FAR DID PROF LOURENS DU PLESSIS'
EARLY VIEWS AND INTERPRETATIONS ON
ABORTION GO IN DEFENCE OF LIFE AND GOD?
}

\section{A mother-to-be trading in her life for that of her unborn?}

It may be inferred from a 1978 article (among his earliest although coauthored) that as a jurist Du Plessis was supportive, amidst a very restrictively held pro-life view, of a "pro-choice" view being exercised in favour of the life of an unborn over that of its mother when an emergency warranted a therapeutic abortion:

\begin{abstract}
"abortion should under all circumstances be punished as a form of murder; ... the only ground of justification which should be recognised (legally and otherwise) for abortion in the event of an emergency, is a threat to the life or health of the mother (but even here it should still be left to the mother and other interested parties to make a choice).
\end{abstract}

It is contended that the view of affording the mother ("and other interested parties", presumably the husband and doctor-provider) the right to choose to forego her own life to save that of her child, although remarkably progressive for its time, will garner little support and goes far beyond the "choice" to abort currently offered to women by the CTOPA, and may for this reason be constitutionally limited. Furthermore, his view is also controversial because of the ethical question it raises as to just how far Du Plessis' early position was really in defence of life and God. This is therefore further interrogated with him in paragraph 6 below.

It is logically expected that, if the pregnancy (foetus) threatens the life of the mother-to-be, a doctor, whether or not he or she may invoke section 15(1) of the Constitution as a defence in objecting to performing an abortion, will be duty-bound to choose "the" life of the mother over "a" potential human life and provide an abortion as an emergency service when saving the woman's life, or preventing further harm to it, is at stake. This is logically inferred from the fact that the mother's life would be deemed the more valuable of the two. Abortion is not a form of murder. ${ }^{50}$

Although objecting providers may be able to invoke section 15 , or even section 23(1) (unfair labour practice) of the Constitution, their right to object may be limited by section 36 of the Constitution when compelling medical cases or emergencies necessitate that abortions be performed. ${ }^{51}$ While an abortion based on eugenic grounds is seen as a means by which the State is able to protect both a woman's health and her life itself, Du Plessis' view suggests that women may opt to forfeit both these protections in favour of

49 English translation (my emphasis added in italics). Barnard, Du Plessis, Kempff and Oosthuizen “Aborsie: 'n Juridiese, Etiese en Regsetiese Vraagstuk" 1978 43(4) Koers 349.

50 $v$ Mshumpa [2008] (1) SACR 126 (E).

51 S 9 (conscience clause) of the ASA allowed doctors to refuse to perform an abortion without having to proffer any reasons. The CTOPA does not contain a similar clear provision. 
the life and health of her unborn. While Du Plessis may accord a very high priority to the sanctity of life, he distinguishes between a life that is worthy of protection and one that is not. Therefore, valid questions that can be asked are: How really different is the "source" or "origin" of the life of the mother and that of her unborn? How is her life any less sacred, and taking it any less than murder, even when it is her personal choice to give it up?

\section{(ii) Conception and contraception: interpreting the ASA to treat the unborn as more or less human?}

In 2013, the then Minister of Health expressed the view that young girls are "using abortion as contraception", which confirms that abortion had become a form of failed contraception in South Africa. ${ }^{52}$ However, an interpretation of the ASA meant that the reverse was possible, that is, that contraception was a form of abortion. The ASA does not make any legal distinction between an early or late abortion on the basis of the "age" of an unborn. Thus, actions that either complied with the "definition" of abortion, or abortions which did not meet with the requirements of the ASA, were both deemed to be equally criminal. However, there were subtle variations in the respective translations of the definition of abortion in the English (official) and Afrikaans versions of the ASA. Section 1 in the official version, which is of interpretative value, created ambiguity ${ }^{53}$ when it defined abortion as "the abortion of a live foetus of a woman with intent to kill such a foetus".

In doing so it confounded matters because it did not meet the necessary standard expected of a definition, and could therefore allude to life either starting early with conception (that is, when the female ovum is fertilised by male sperm to form a zygote), or later with implantation (that is, after the zygote becomes implanted in the uterus or womb of the woman as an embryo). In this definition the term "abortion" was inadvertently used to explain what was meant by it and therefore essentially defied its purpose. The translation of key words in the definition therefore had significant interpretative implications for either "editing" the right to life in or out, which proved problematic for Du Plessis' pro-life views, but which he as a jurist was duty-bound to solve through rational interpretation of the law.

The English definition of abortion brought Du Plessis face to face with interpretational challenges presented by the practical use of the "contraceptive", namely, the intrauterine device (IUD), because it raised ethical questions about the beginning of life. If therefore life began with conception, as many pro-lifers speculate it does, then it was also a real fact that the IUD did not prevent conception, but merely prevented the implantation which occurs after conception. Strauss argued that, although

\footnotetext{
52 See Halata "Teens Using Abortion as Contraception" 29 July 2013 http://www.iol.co.za/ lifestyle/family/kids/teens-using-abortion-as-contraception-1.1554238\#.U_T2nVeH9w1 (accessed 2015-01-05)

53 Hawthorne (Unpublished LLD Thesis, University of Pretoria 1982) 249.
} 
"technically" an IUD was an abortifacient, that legally its use did not amount to an unlawful abortion. ${ }^{54}$

Similarly, Du Plessis ${ }^{55}$ argued that using an IUD was not prohibited by the ASA because the Act, strictly speaking, protected the point of implantation and not the point of conception. In support of this view, Du Plessis deemed the Afrikaans version of section 1 as providing more clarity, and giving a better indication of the type of abortion that the Act intended to invalidate:

"vrugafdrywing is die afdrywing [expulsion or removal] van 'n lewende vrug van 'n vrou met die opset om dit te dood".

Logically, this confirms that the ASA was "liberal" and that Du Plessis, however, "pro-life" he deemed himself to be, did not support the protection of life from the moment of conception. However, Du Plessis believed that prolifers may be taking life too far when they deem an abortion that occurs spontaneously (miscarriage) to still be an abortion.

Today, given legalisation, using contraceptives like the IUD is hardly an issue. The definition of "termination of pregnancy" in section 1 of the CTOPA requires implantation and refers to an abortion that is purposely induced, rather than one that occurs spontaneously (miscarriage) as follows:

"means the separation and expulsion, by medical [through drugs] or surgical [through instrumentation] means, of the contents of the uterus of a pregnant woman".

There is a clear indication in both the $A S A^{56}$ and the CTOPA ${ }^{57}$ that a foetus is capable of suffering severe physical or mental abnormality, and sustaining injury (ASA). Given that currently a medical abortion (by surgical means) may be delayed because it may be initiated only once a foetus is detected, there is no such thing as a "quick" abortion. Specialist doctors in South Africa are currently also performing open (intra-uterine) foetal surgery in terms of which the uterus is opened and the foetus is exposed (as in a caesarean section birth). However, the foetus remains dependent on the placenta (life line which connects it to the mother), and is either returned to the uterus or birth takes place. Doctors are literally opening a window to life in the womb in order to avert pain and suffering to a growing foetus and give it a greater chance of a normal life. This begs the question whether these advancements, given that the unborn may in some cases be partially delivered (while remaining attached to its mother) and returned to the womb, do not also mean that the "moment" that life starts may yet have to be reviewed or revised in South Africa? It does, however, appear that, according to the widely accepted definition of "live birth" by the UN World Health Organisation (WHO), only a foetus that is completely expelled from

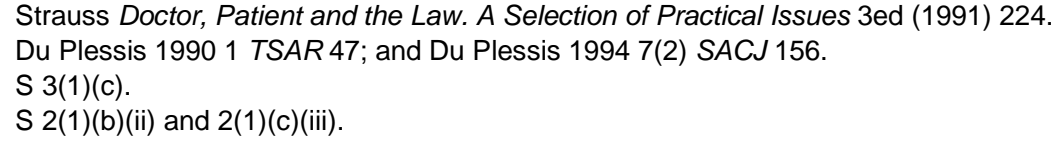


its mother's body, even if still attached to the mother's body via the umbilical cord, will be considered to comply therewith. ${ }^{58}$

\section{DID CHRISTIANITY HAVE AN IMPACT ON THE SOUTH AFRICAN LAW PERTAINING TO ABORTION, ON WHEN LIFE STARTS, AND ON THE PROTECTION OF THE UNBORN?}

Christianity, as is borne out by the population censuses taken just prior to democracy in 1991 (76.9\%), ${ }^{59}$ and thereafter in 1996 (75.5\%) and 2001 $(79.8 \%),{ }^{60}$ held a clear majority position among religions in South Africa. The latest (2011) census, however, excludes religion as a consideration and therefore it can only be speculated that Christianity is still the dominant religion.

Although the ASA equally applied to, and discriminated against, all women regardless of their race, it nonetheless on more than one count discriminated between black and white women, given the latter's preferred racial and class hierarchy over all other women.

The NP Government discouraged white women from seeking legal abortions, and through incentives, like tax perks, encouraged the growth of the minority white population. ${ }^{61}$ In fact:

"While most religious groups in South Africa opposed legalization of abortion, the Dutch Reformed Church ... not only opposed the new law but propagated the belief that the white population must grow to maintain its supremacy ... By contrast, contraception was promoted for black ... women.

A blind eye was also turned to black African transgressors of the ASA and its common-law predecessor in the hope of stemming the growth of an already burgeoning majority black. African population. ${ }^{63}$ Ironically, white women were able to secure legal abortions locally based on psychiatric ${ }^{64}$ grounds (which accounted for the most abortions), or go abroad to countries of colonial origin like England and the Netherlands, if they could afford to do so. ${ }^{65}$

58 See Cole "Marvel of Foetal Surgery" 16 October 2014 Daily News http://www.iol.co.za/ dailynews/news/marvel-of-foetal-surgery-1.1765827\#.VDe4C1eH9w0 (accessed 2015-0105). See also Carstens and Du Plessis "Medico-legal Aspects Pertaining to Children" in Boezaart (ed) Child Law in South African Law (2009) 588.

59 Du Plessis and Gouws 2000 14(2) Emory International LR 659.

60 See "Census 2001: Primary Tables South Africa Census '96 and 2001 Compared" Report No. 03-02-04 (2001) published by Statistics South Africa in 2004 http://www.statssa.gov.zal census01/html/RSAPrimary.pdf (accessed 2015-01-05).

61 Guttmacher, Kapadia, Naude and De Pinho "Special Report. Abortion Reform in South Africa: A Case Study of the 1996 Choice on Termination of Pregnancy Act" 1998 24(4) International Family Planning Perspectives 191. See also Rebouché "The Limits of Reproductive Rights in Improving Women's Health" 2011 63:1:1 Alabama LR 8. Guttmacher et al 1998 24(4) International Family Planning Perspectives 191.

63 Rebouché 2011 63:1:1 Alabama LR 7.

64 Strauss Doctor, Patient and the Law. A Selection of Practical Issues 3ed 218.

65 Guttmacher et al 1998 24(4) International Family Planning Perspectives 191. 
According to the common law, a person is legally deemed to come into existence at birth. Hence, in terms of South African law, legal subjectivity only starts at birth. Legal personality therefore begins when the birth is complete, that is, when the child is separated from its mother and is breathing. ${ }^{66}$ Although protective legal measures exist in both the common law and statutory law to safeguard the interests of the unborn, support for the definition of a child as a person under the age of 18 years is found in the Constitution ${ }^{67}$ and the Children's Act. ${ }^{68}$ Both link the definition of "a child" to age. That the law had, during apartheid, not formally accorded the foetus any legal status until it had been born was probably acceptable, given that abortion was illegal and that therefore an unborn had a greater chance of survival than it would currently have. The law then, as now, also provided additional protection to an unborn. For example, the nasciturus fiction, in terms of which an unborn is deemed to have already been born when it is to its advantage, would help an unborn, if subsequently born alive, to secure its interests in matters pertaining to succession. However, nothing would, for example, legally preclude an unscrupulous mother-to-be from entirely circumventing its application by furtively seeking an abortion in order to stand a better chance of augmenting her own share of the inheritance.

\section{(i) Du Plessis on the nasciturus fiction and the disadvantaged foetus}

Although indicating that the ASA did not make provision for any ring-fencing of the moment of life, Du Plessis already in 1978 had regarded the commonlaw position that legal subjectivity only starts with live birth as archaic:

"In this respect our law is obsolete. The origin of life is today no longer tied to a mysterious connection between body and soul. Why can our law then not make use of modern medico-scientific tools to define its own moment of life?"69

It would therefore appear that for Du Plessis the fact that life may clinically also begin with "brain birth", in terms of the latest research, would have been a serious consideration.

In 1976 Du Plessis, ${ }^{70}$ in one of the first articles in which he briefly mentions abortion, pointed out that the reason why the foetus was disadvantaged by the nasciturus rule was simply because the premise upon which its operation depends, namely, subsequent live birth, is not present because of an abortion.

\footnotetext{
Carstens and Du Plessis in Boezaart (ed) Child Law in South African Law 588 and 593.

$\mathrm{S} 28(3)$.

S 17 of Act 38 of 2005.

English translation. Barnard et al 1978 43(4) Koers 346.

Du Plessis Vraagstukke Rondom die Lewe Juridies Besien (1976) 17.
} 
Du Plessis was critical of the judgment in Christian League of South Africa $v$ Rall ${ }^{71}$ which held that the nasciturus rule could not be invoked to found a right to prevent a lawful abortion under the ASA.

In two similar articles written by Du Plessis in 1990 and $1991,{ }^{72}$ it becomes evident that Du Plessis did not see the requirement of "live birth" as an insurmountable obstacle. The 1991 article highlights that he was positively reliant on a Christian consciousness which he felt must be used to persuade the then Christian majority of the preciousness of pre-natal life. In both articles he expressed the view that the South African law was woefully remiss in providing sufficient protection to the unborn, and that the time had arrived to consider two amendments to the law. First, he recommended according legal subjectivity and personality to the foetus through an extension of the nasciturus rule as a possible "preventive protection" measure. Secondly, in what could probably be considered by many to be an extreme and unaffordable measure, he suggested that the ASA be amended to provide that every application for an abortion be heard in judicial proceedings, in which an unborn is represented by a curator ad litem. While his second argument highlighted that he believed that abortion should be made more difficult to obtain, and that more protection ought to be afforded to a foetus, he was aware of the limitations of his argument that can be inferred from his own words in the 1990 article that "[t]he attitude[s] of South African jurists to existing abortion laws vary". ${ }^{73}$

\section{(ii) Du Plessis on linking the ASA to the lawful abortion of an unborn of mixed race}

According to Strauss, the reference in the ASA to the contravention of the Immorality Act 23 of 1957 in defining a legal indication for an abortion which pertained to the foetus having been conceived in unlawful (later amended to illegitimate) intercourse,

"had given rise to a fallacy that conception of a foetus in consensual 'BlackWhite' immorality now constitutes an indication for abortion".

Not so, according to Du Plessis' interpretation thereof:

"This question becomes similarly topical when we venture into the field of sexual offences: should adultery be a crime in our law and if so, on which grounds ... to which extent should (which forms of) abortion be prohibited by sanction .... in our Immorality Act .... and then especially section 26 thereof which prohibit acts of immorality between White and non-White [; is it] in all respects tenable and defensible?" 75

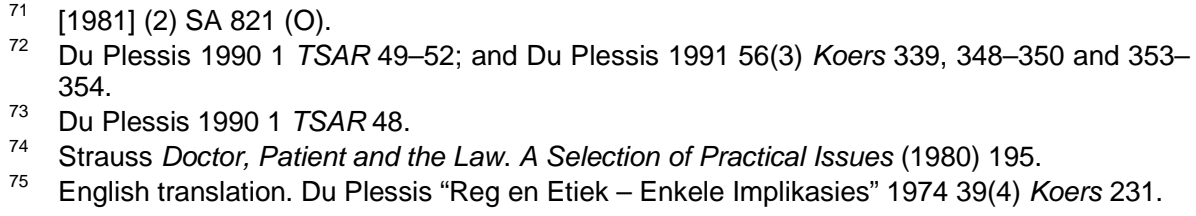


The Immorality Act was repealed by the Immorality and Prohibition of Mixed Marriages Amendment Act 72 of 1985, which finally lifted the prohibition of sexual relations between interracial couples. However, Du Plessis had raised a valid question in the quotation cited above: Whether during the time that this legislation was still in operation, given the period of its overlap with the ASA, did this not mean that it also justified a further, albeit racially-based and "immoral", legal basis to procure an abortion in terms of the ASA which the apartheid Government would have been legally obliged to condone? This implied that it was a racist law, given that it was possible to justify its use to deprive an unborn of life purely on the basis of its "mixed" race.

\section{(iii) Du Plessis on other "pro-life" legislation?}

Du Plessis ${ }^{76}$ had mentioned two early examples in South African law (pertaining to maternity leave and pregnant women facing the death sentence or being imprisoned) that suggest that it favoured a pro-life approach and protected unborn life. The execution of the death sentence of a pregnant woman was delayed until after she had given birth, and special provision was made for the release of prisoners with advanced pregnancies. However, I contend that currently this is no longer the case because, although the death penalty may have subsequently been abolished, female prisoners can still access abortion, and unequal maternity and paternity benefits still exist as patriarchal constructs.

The equality clause (section 9) of the Constitution takes cognisance of the different biological roles of men and women in relation to reproduction by preventing discrimination on the ground of pregnancy.

Regulations currently do not make it possible for "inmates" (previously "prisoners") in South Africa to have an abortion on request during the first trimester in terms of the CTOPA at State expense. ${ }^{77}$ While it may therefore seem that an unborn is protected during this period, I contend that this is not so. It would appear that the Constitution, ${ }^{78}$ in addition to its equality provision, also permits inmates to consult with, and be attended to, by their own private medical practitioners at their own cost, and therefore provides women with a loophole, and a means with which to obtain a first trimester abortion with a doctor's assistance; and neither could be found guilty of having transgressed the CTOPA or the Correctional Services Act. Further, that an inmate will probably stand a better chance of having a safe abortion than a poor black woman living in a township who has to resort to an illegal abortion or abortificants.

Du Plessis also opined that the fact that statutory provision is made for maternity leave, can be seen as a positive measure by the State in favour of protecting the life of an unborn. However, I contend that this is only a start

Du Plessis 19901 TSAR 54.

77 See Regulation 7(9)(b) of the Regulations accompanying the Correctional Services Act 111 of 1998 which were promulgated in 2004 and amended by the Correctional Services Amendment Act 25 of 2008.

78 S 35(2)(f)(iv). 
and not enough. Section 25 of the Basic Conditions of Employment Act ${ }^{79}$ makes provision for four months' maternity leave for new mothers. Fathers have to rely on Section 27 of the same Act, which gives anyone three days of paid family-responsibility leave in a year, when a child is born. This is an indication of the marginal value attached to the roles of a father, and the State in ridding society of patriarchal constructs.

\section{RECENT RUMINATIONS WITH DU PLESSIS ABOUT HIS VIEWS}

The following are some of the thoughts that Prof Du Plessis has shared with me, interspersed with my own analysis thereof.

Although it appears from Du Plessis' last publication on abortion in 1996 that his view of both abortion and organised religion has "softened", it does not spell theological fatigue, a change of heart or even indifference to both. This is unremarkable because there is not only one strand of Christianity that is right. Du Plessis deemed the ASA to be too liberal and the defences that it had introduced as too broad. Yet the then status quo must at least have given Du Plessis some sense of control over the situation because the ASA afforded him an assurance of fatherhood in ways that the CTOPA does not do for men today, given that it assures women alone of a choice to abort.

That he was able to have children made the fact that they were all girls irrelevant because today Du Plessis is the proud grandfather of grandchildren, including grandsons. They were all born after democracy and the legalisation of abortion, and therefore a thought that does give him cause for concern is the fact that any one of them could have been aborted at a daughter's volition, and that he would have been powerless to do anything about it.

I questioned Du Plessis about the contradictory radicalism implicit in the very conservative anti-abortion view expressed in his 1978 publication. He conceded that an unborn in such an (emergency) case also has to be born wanted. A similar view is confirmed in his 1996 publication with regard to abandoned and unwanted children.

Du Plessis is still sympathetic to a pro-life view, and although he is, by his own admission, not a good defender of pro-choice; he is no longer absolutely or even inflexibly anti-abortion, especially in cases where there is little room for manoeuvre. A typical example would be the emergency situation, where the life of the mother-to-be is in danger and needs to be saved. In view of the circumstances and the fact that there is nothing else that can be done about the situation, he will agree that the abortion is necessary to save the mother's life. At the same time, Du Plessis still largely resonates with the radical "pro-choice" view advocated in 1978, which affords a mother-to-be the choice to trade in her life for that of her unborn in such an emergency situation. While this may seem contradictory, he still respects her choice to do so.

$79 \quad 75$ of 1997. 
Ultimately, Du Plessis believes that the choice that anyone exercises regarding abortion is a very personal one.

\section{$7 \quad$ CONCLUSION}

The apartheid ASA, paradoxically, did not confer all rights on an unborn. Although it had little to do with Christianity and permitted abortion, the fact that it had policed abortion through law may have made it more acceptable to those South Africans who favoured a pro-life view. With democracy, religion was not mandated to influence the legal arena. Inevitably, the revering of human life succumbed to political considerations. The legalisation of abortion therefore meant that a blind eye was turned to the wishes of especially those for whom religion and culture form an integral part of their social fabric and lived realities. A reliable, though dated (2003-2006) study $^{80}$, concludes that most South Africans are not only against abortion but also viewed it as "wrong". Du Plessis' pro-life views lend both voice and weight to such a position.

This article has highlighted that Du Plessis was able to hold anti-apartheid views and play an instrumental role at the coalface of shaping South Africa's first Bill of Rights, while at the same time holding early pro-life views that may not have augured well for an assured future pro-abortion law. It is therefore contended that, while Sarkin's criticism of his supervisor may have been partly justified, it was probably easier for Sarkin to be able to don a constitutional hat to critique Du Plessis' pro-life view (which appears from this article to be decidedly more pro-choice than pro-life) and, furthermore, to find legal support for his own pro-choice views in the fact that South African law recognises only an unborn as a child or person when it is in fact born alive. It is contended that Sarkin's views may, like Du Plessis', also have been influenced by his own subjectivities, given that he has been described as a "leading Jewish intellectual". ${ }^{81}$ A valid question to ask therefore is whether Sarkin's rationale for his pro-choice view was entirely uninfluenced by the religion that he was born into, or whether it is merely coincidental that Jewish law, ${ }^{82}$ too, deems life to begin with live birth? Moreover, given, too, that Jewish law requires only that the unborn should have emerged halfway from its mother's body to be deemed a human, it will be interesting to know what Sarkin will make of the fact that with intra-uterine surgery the unborn is partially removed from its mother's body, and may even be returned to it.

I also engaged Du Plessis about how he found the experience of supervising Sarkin, given the divergency of their views. He was gracious enough to admit that, in hindsight, he may have been too hard on Sarkin. I believe that, given Du Plessis' pro-life views and his instrumental role in

80 Mncwango and Rule "South Africans Against Abortion" no date Social Attitudes Survey 6-7 http://www.hsrc.ac.za/uploads/pageContent/1607/South\%20Africans\%20Against\%20Aborti on.pdf (accessed 2015-01-05)

81 Kaplan "Reconciliation and Healing: A South African Jewish Perspective" 1999 63(2) The Reconstructionist 84.

82 See Rich "Birth and the First Month of Life" 1997-2011 Judaism 101 http://www.jewfaq. org/birth.htm (accessed 2015-01-05). 
framing the interim Constitution, and Sarkin's doctorate favouring pro-choice views, that they had lost a golden opportunity to join forces and combine their divergent academic views on abortion towards finding a more workable, balanced solution for South Africa at the time that it needed expertise, while they were best placed to provide it. This was a pity because, as this article has highlighted, Du Plessis was able to set his personal views aside when they conflicted with his professional interpretations regarding the application of the ASA, and to again do so in terms of the pro-choice provisions of the Constitution which followed. Their different views may not have been so opposed after all.

If Du Plessis were asked today to speculate about the beginning of life, he may be ambivalent. When I asked Du Plessis whether his earlier-held (conservative) views on abortion had changed, and he replied that he was not really sure, I was not surprised, because, given that being pro-life does not necessarily always have to mean being anti-choice, is evidenced in his own more controversial views. His honesty remains humbling and confirms for me the wisdom behind an adage that I read somewhere, which goes along the lines that "we are often most in the dark when we are the most certain, and the most enlightened when we are the most confused".

I contend that it would not have been better, nor would it have mattered, had the Constitution, instead of adopting a Solomonic neutral position (tantamount to fence-sitting), contained a clear abortion clause which guaranteed the right to abortion, given that its emphasis on female reproductive rights "locks in" support for abortion. However, this does not necessarily imply that a constitutional challenge, which has yet to occur, does not stand a chance to amend the status quo to provide protection to an unborn. Du Plessis may have written his last word on abortion, but agrees that a last word on the contentious topic has yet to be written. 